Збірник наукових праць Української державної академії залізничного транспорту

УДК 656.211

Кандидати техн. наук І.В. Берестов, Г.В. Шаповал, магістр Ю.В. Валуйська

candidates of techn. sciences I.V. Berestov, A.V. Shapoval, master Yu.V. Valujska

\title{
ВИБІР РАЦІОНАЛЬНОЇ ТЕХНОЛОГІЇ ОБСЛУГОВУВАННЯ СОСТАВІВ У ПАСАЖИРСЬКОМУ КОМПЛЕКСІ
}

\section{THE SELECTION OF A RATIONAL MAINTENANCE TECHNOLOQY OF THE TRAIN ASSEMBLY IN A PASSENGER COMPLEX}

\section{Представив д-р техн. наук, професор С.С. Альошинський}

\begin{tabular}{lrrr}
\multicolumn{1}{c}{ Вступ. } & \multicolumn{2}{c}{ Сучасні умови } & роботи \\
залізничного & транспорту & у & сфері \\
пасажирських & перевезень & \multicolumn{1}{c}{ вимагають } \\
підвищення & ефективності & та & якості \\
обслуговування & пасажирів & в & умовах \\
жорсткої конкуренції & на & ринку \\
пасажирських перевезень [1]. & &
\end{tabular}

\begin{tabular}{l}
\multicolumn{4}{c}{ Постановка проблеми. Основним } \\
напрямком підвищення конкуренто- \\
спроможності на ринку пасажирських \\
перевезень є пошук ефективних технологій \\
управління ресурсами пасажирського \\
комплексу, які дозволять знизити \\
збитковість пасажирських перевезень за
\end{tabular}
напрямком осова ороблеми. Основним спроможності на ринку пасажирських перевезень $є$ пошук ефективних технологій управління ресурсами пасажирського комплексу, які дозволять знизити (1)

Збірник наукових праць УкрДАЗТ, 2013, вип. 137 
рахунок приведення можливостей залізниць у відповідність до попиту на перевезення в різних сполученнях.

Протягом останніх років відбувається поступове зростання обсягів пасажирських перевезень на фоні суттєвого зносу пасажирського рухомого складу та дуже повільних темпів його оновлення. Така ситуація вимагає оптимізації технології обслуговування составів поїздів у пасажирському комплексі для більш раціонального використання робочого парку пасажирських вагонів в умовах дефіциту рухомого складу [2].

Аналіз останніх досліджень та публікацій. Однією 3 найбільш слабких ланок у пасажирському комплексі $\epsilon$ технологія обслуговування поїздів на пасажирських технічних станціях, яка потребує удосконалення.

Виникнення й розвиток пасажирських комплексів та безпосередньо пасажирських технічних станцій обумовлено процесом спеціалізації станцій у вузлах та виділенням пристроїв для виконання технологічних операцій з підготовки у рейс составів пасажирських поїздів у самостійний комплекс. У зв'язку з цим із ранжирних парків, розташованих на коліях пасажирських станцій, було сформовано комплекс окремих парків та пристроїв, спеціалізованих для очищення, переформування, ремонту, екіпірування та відстою готових составів, що перетворився на окрему пасажирську технічну станцію [3].

Теперішній стан пасажирських технічних станцій має ряд суттєвих недоліків, які не завжди дозволяють здійснювати якісну підготовку до рейсу составів пасажирських поїздів. До них належать: недостатній колійний розвиток, необхідність передачі составів на відстій на проміжні та вантажні станції вузла, недосконалість системи очищення вагонів від шлаків та сміття, недостатня кількість вагономийних машин та можливість використання частини 3 них тільки в теплий період року, відсутність на багатьох станціях ремонтно-екіпірувальних депо, конструктивні недоліки схем (відсутність потоковості переміщень у процесі обробки, наявність пересічень поїзних та маневрових маршрутів і т. ін.), як наслідок поступового збільшення потужностей окремих елементів в умовах відсутності резервів території для раціонального розташування додаткових колій та пристроїв [4].

Аналіз теоретичних досліджень та вимог нормативних документів показав, що в теперішній час розроблено типові схеми цих станцій, які можуть бути рекомендовані для застосування в конкретних умовах. Не потребують додаткового дослідження питання аналітичного розрахунку потрібного колійного розвитку й технічного оснащення пасажирських технічних станцій, вибору їх числа та місця розташування у великих залізничних вузлах $[5,6]$.

У сьогоднішніх умовах технічне оснащення пасажирських технічних станцій не повною мірою відповідає сучасним вимогам до обсягів роботи. Станції виконують цикл операцій, передбачений типовим технологічним процесом роботи, не в повному обсязі. Окремі состави відправляються у рейс у незадовільному стані, що негативно впливає на якість перевезень. Тому необхідно приділяти увагу питанням визначення оптимальних обсягів роботи, завантаженості пристроїв та відповідного технічного оснащення цих станцій [7].

Для цього запропонована система критеріїв оцінки техніко-технологічних параметрів пасажирських технічних станцій [8], яка містить як кількісні, так і якісні показники: екологічна безпека, маневреність та ін. Розроблена імітаційна модель роботи пасажирської технічної станції на базі використання пакета прикладних програм MATLAB, яка враховує топологію схеми, структуру потоку та дозволяє виконувати моделювання роботи. 
Упровадження швидкісного руху викликало потребу удосконалення процесу поїздоутворення пасажирських составів на пасажирських технічних станціях. Для вирішення цього завдання було запропоновано адаптивну модель поїздоутворення, яка використовує математичний апарат нечіткої логіки й дозволяє врахувати неповноту та нечіткість вхідної інформації [9].

Для удосконалення технології оперативного регулювання поїздоутворення на пасажирських технічних станція було запропоновано методику прогнозування [10], яка дозволяє отримати із задовільною точністю прогнози пасажиропотоків 3 урахуванням глибини горизонту прогнозування та строків прийняття відповідних рішень.

Постановка

завдання. Для удосконалення технології роботи пасажирського комплексу необхідно здійснювати вибір оптимальних технічних та технологічних параметрів у взаємодії роботи пасажирської i пасажирської технічної станцій. Одним із основних технологічних параметрів, який потребує удосконалення, $\epsilon \quad$ технологія обслуговування составів.

\section{Виклад основного матеріалу} дослідження. Для вибору раціональної технології обслуговування составів у пасажирському комплексі може бути використаний метод сітьового програмування. Він дозволяє визначити оптимальну за часом витрату праці, вартість та тривалість обслуговування пасажирського состава, виявити операції, що виконуються на критичному шляху, визначити допустимі витрати часу на інші операції, розглянути можливість суміщення окремих операцій та професій [11].
Процес обслуговування состава у пасажирському комплексі може бути подано у вигляді орієнтованого графу $Q=(P, R) \quad$ (рис. 1). Множина вершин $p_{i} \in P-$ це події, які відбуваються 3 пасажирськими вагонами при виконанні технологічних операцій, множина дуг графа $r_{i, j} \in R$ - це роботи, що з'єднують початкову подію $P_{i}$ та кінцеву подію $P_{j}$. Кожна робота має свою тривалість $t_{i j}$.

Для визначення обмежуючих технічних i технологічних операцій iз пасажирським составом необхідно для розробленого графа $Q$ визначити критичний шлях, який має найбільшу тривалість та буде визначати мінімальні часові витрати на виконання всіх робіт. Несвоєчасне виконання робіт, які належать критичному шляху, буде призводити до зриву своєчасного терміну виконання всього циклу обробки состава.

Для того, щоб будь-яка подія $P_{j}$ здійснилася, необхідно, щоб були закінчені всі роботи $\left(P_{i 1} ; P_{j}\right),\left(P_{i 2} ; P_{j}\right), \ldots,\left(P_{i r} ; P_{j}\right)$, які входять до цієї події. Множину робіт, які входять до цієї події, позначимо $U_{j}^{+}$. Якщо для подій $P_{i 1}, P_{i 2}, \ldots ., P_{i r}$, якими починаються роботи, що входять до $\boldsymbol{j}$-ї події (роботи множини $U_{j}^{+}$), ранні терміни здійснення відомі $-t_{p}\left(i_{1}\right), t_{p}\left(i_{2}\right), \ldots$, $t_{p}\left(i_{\mathrm{r}}\right)$, то будь-який термін здійснення $j$-і події, який позначений як $t_{\text {вз }}(j)$, не може початись раніше, ніж відбудуться всі моменти $t_{p}\left(i_{1}\right), t_{p}\left(i_{2}\right), \ldots, t_{p}\left(i_{\mathrm{r}}\right)$ та будуть виконані всі роботи, які входять до j-ї події, тобто

$$
t_{\text {вз }}(j) \geq \max _{i, j \in U_{j}^{+}}\left\{t_{p}\left(i_{1}\right)+t_{i, j}\right\} .
$$




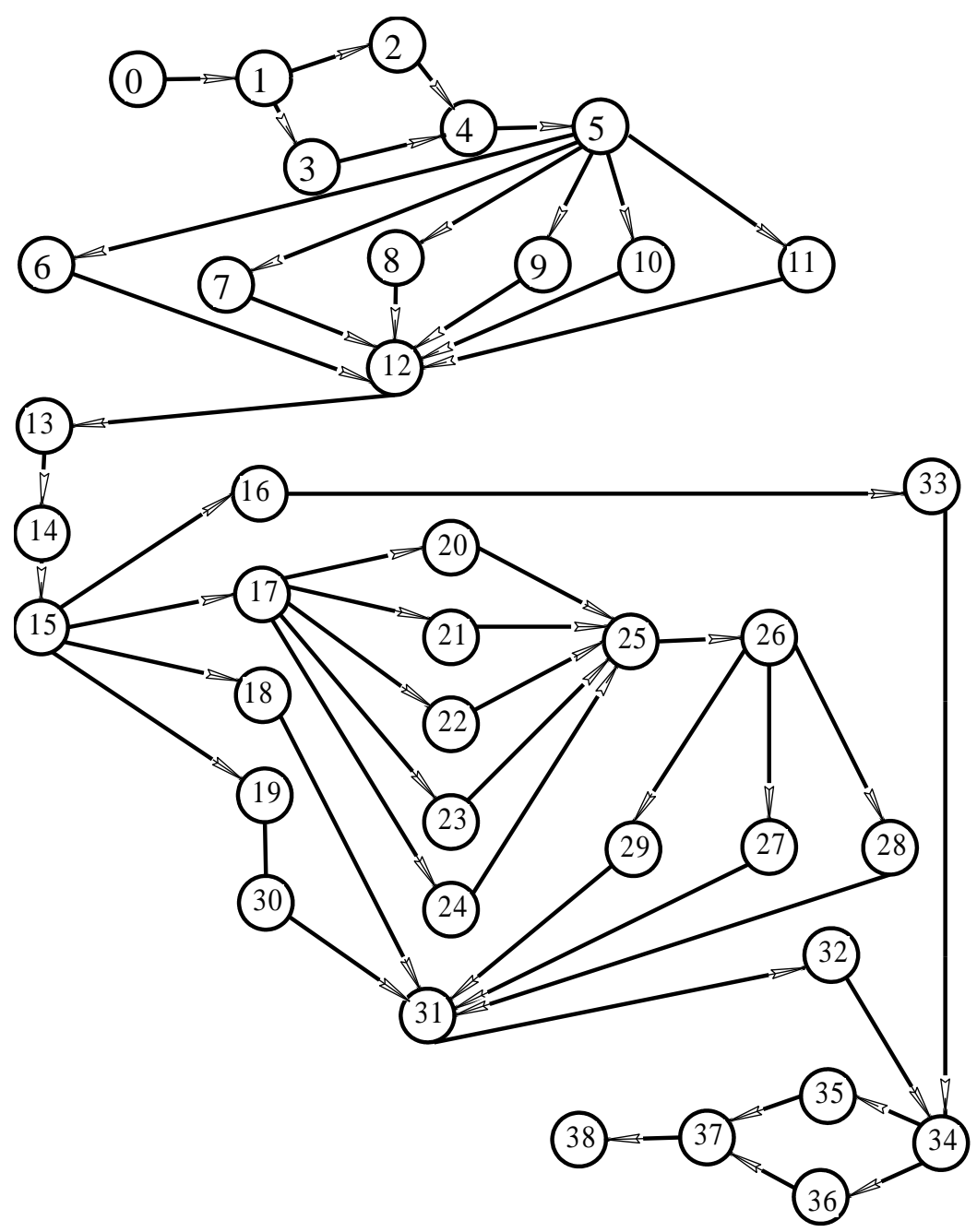

Рис. 1. Граф обслуговування пасажирського составу

Таким чином, найбільш ранній із можливих термін $t_{p}(j)$, тобто мінімально необхідний час між здійсненням вихідної події та $j$-ї події, визначається за роботами максимального шляху, який передує $j$-й події, тому що раніше ця подія здійснитися не може

$$
t_{p}(j)=\max _{i, j \in U_{j}^{+}}\left\{t_{p}\left(i_{1}\right)+t_{i, j}\right\},
$$

де $i$-номери всіх попередніх подій за числом вхідних до $\boldsymbol{j}$-ї події робіт.

3 другого боку, роботи, які виходять із $j$-ї події $\left(P_{j} ; P_{k 1}\right),\left(P_{j} ; P_{k 2}\right), \ldots,\left(P_{j} ; P_{k q}\right)$, утворюють множину робіт $U_{j}^{-}$. Припустимо, що для всіх подій $P_{k 1}, P_{k 2}$, ...., $\quad P_{k q}$, якими закінчились роботи множини $U_{j}^{-}$, найбільш пізні терміни їх здійснення уже відомі, тобто відомі значення $t_{n}\left(k_{1}\right), t_{n}\left(k_{2}\right), \ldots, t_{n}\left(k_{\mathrm{q}}\right)$. Тоді допустимим терміном здійснення $\boldsymbol{j}$-ї події, який позначимо $t_{\partial n}(j)$, може бути тільки такий термін, який, будучи складеним iз тривалістю будь-якої роботи множини $U_{j}^{-}$ (вихідної із $\boldsymbol{j}$-ї події), дасть момент часу, що не перевищує жодного із термінів $t_{n}\left(k_{1}\right)$, $t_{n}\left(k_{2}\right), \ldots, t_{n}\left(k_{\mathrm{q}}\right)$. Тобто 


$$
t_{\partial n}(j) \leq \min _{i, j \in U_{j}^{-}}\left\{t_{n}(k)-t_{j, k}\right\} .
$$

Таким чином, найбільш пізній із допустимих термінів здійснення $\boldsymbol{j}$-ї події, тобто максимально допустимий час між вихідною та $\boldsymbol{j}$-ю подією при незмінному критичному шляху, буде термін, який визначається рівністю

$$
t_{n}(j)=\min _{i, j \in U_{j}^{-}}\left\{t_{n}(k)-t_{j, k}\right\},
$$

де $k$ - номери всіх наступних подій за числом вихідних із $\boldsymbol{j}$-ї події робіт.

Для подій, які належать критичному шляху $\left(\mu_{\kappa p}\right)$, ранні та пізні терміни здійснення подій збігаються. Тобто $t_{p}(j)=t_{n}(j)$ тоді і лише тоді, коли $P_{j} \in \mu_{\kappa p}$. Це той шлях виконання робіт, який з'єднує початкову та кінцеву події графа та має максимальну тривалість.

У таблиці наведено перелік подій, які відповідають графу $Q$.

Для розробленого графа $Q \quad 3$ урахуванням характеристик робіт та подій, що входять до його складу, було визначено ранні й пізні терміни здійснення подій та встановлено критичний шлях обслуговування составів у пасажирському комплексі. Критичний шлях наведено на рис. 2.

Таблиця

\begin{tabular}{|c|c|c|c|c|}
\hline Подія & Зміст події & $\begin{array}{c}\text { Попередня } \\
\text { подія }\end{array}$ & $\begin{array}{c}\text { Код } \\
\text { роботи }\end{array}$ & $t_{i j}, \mathrm{Хв}$ \\
\hline 1 & 2 & 3 & 4 & 5 \\
\hline 1 & Огляд состава поїзда під час руху & 0 & $0-1$ & 2 \\
\hline 2 & Відчеплення поїзного локомотива & 1 & $1-2$ & 5 \\
\hline 3 & Висадка пасажирів & 1 & $1-3$ & 15 \\
\hline 4 & Причеплення маневрового локомотива & $\begin{array}{l}2 \\
3\end{array}$ & $\begin{array}{l}2-4 \\
3-4\end{array}$ & $\begin{array}{l}3 \\
3\end{array}$ \\
\hline 5 & $\begin{array}{l}\text { Подавання состава в парк приймання технічної } \\
\text { станції }\end{array}$ & 4 & $4-5$ & 7 \\
\hline 6 & $\begin{array}{l}\text { Огляд ходових частин, рами, кузова, } \\
\text { гальмового обладнання, ударно-тягових } \\
\text { пристроїв та перехідних площадок }\end{array}$ & 5 & $5-6$ & 35 \\
\hline 7 & $\begin{array}{l}\text { Огляд внутрішнього обладнання, електро- } \\
\text { обладнання, вентиляції та радіообладнання }\end{array}$ & 5 & $5-7$ & 30 \\
\hline 8 & $\begin{array}{l}\text { Огляд установок кондиціонування повітря та } \\
\text { холодильних установок вагонів-ресторанів }\end{array}$ & 5 & $5-8$ & 25 \\
\hline 9 & Огляд системи опалювання та водопостачання & 5 & $5-9$ & 15 \\
\hline 10 & Огляд привода підвагонного генератора & 5 & $5-10$ & 20 \\
\hline 11 & $\begin{array}{l}\text { Сухе прибирання та здавання } \\
\text { робітникам екіпірувальної бригади }\end{array}$ & 5 & $5-11$ & 40 \\
\hline 12 & $\begin{array}{l}\text { Подавання пасажирського состава } \\
\text { вагономийний комплекс }\end{array}$ & $\begin{array}{c}6 \\
7 \\
8 \\
9 \\
10 \\
11 \\
\end{array}$ & $\begin{array}{c}6-12 \\
7-12 \\
8-12 \\
9-12 \\
10-12 \\
11-12 \\
\end{array}$ & $\begin{array}{l}3 \\
3 \\
3 \\
3 \\
3 \\
3\end{array}$ \\
\hline
\end{tabular}

Події та їх зміст по обслуговуванню пасажирського составу 
Продовження таблиці

\begin{tabular}{|c|c|c|c|c|}
\hline 1 & 2 & 3 & 4 & 5 \\
\hline 13 & $\begin{array}{l}\text { Зовнішнє обмивання пасажирського состава на } \\
\text { вагономийному комплексі }\end{array}$ & 12 & $12-13$ & 45 \\
\hline 14 & $\begin{array}{l}\text { Санітарний огляд та безвідчепна санітарна } \\
\text { обробка вагонів }\end{array}$ & 13 & $13-14$ & 30 \\
\hline 15 & Переформування пасажирського состава & 14 & $14-15$ & 25 \\
\hline 16 & $\begin{array}{lll}\text { Відчеплення поштово-багажних } \\
\text { подавання їх на колії обробки }\end{array}$ & 15 & $15-16$ & 10 \\
\hline 17 & $\begin{array}{l}\text { Подавання состава для поточного ремонту в } \\
\text { ремонтно-екіпірувальне депо }\end{array}$ & 15 & $15-17$ & 5 \\
\hline 18 & $\begin{array}{l}\text { Прибирання вагонів до відчіпного та } \\
\text { деповського ремонту, на загальну технічну } \\
\text { ревізію та санітарну обробку }\end{array}$ & 15 & $15-18$ & 5 \\
\hline 19 & $\begin{array}{l}\text { Відчеплення вагонів-ресторанів та подавання } \\
\text { на колії їх обробки }\end{array}$ & 15 & $15-19$ & 10 \\
\hline 20 & $\begin{array}{l}\text { Технічний огляд та ремонт ходових частин, } \\
\text { рами, кузова, гальмового обладнання, ударно- } \\
\text { тягових приладів та перехідних площадок } \\
\text { вагонів }\end{array}$ & 17 & $17-20$ & 90 \\
\hline 21 & 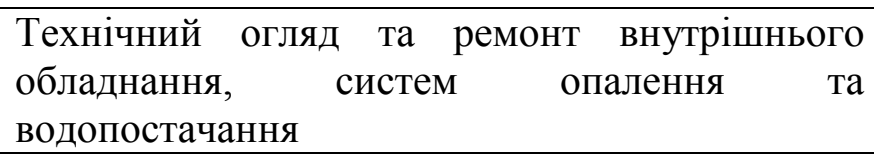 & 17 & $17-21$ & 80 \\
\hline 22 & 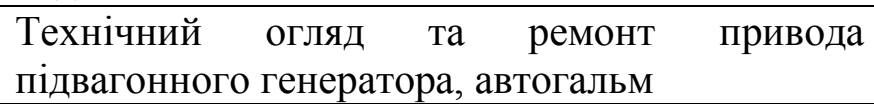 & 17 & $17-22$ & 70 \\
\hline 23 & $\begin{array}{l}\text { Технічний огляд та ремонт електроприладів і } \\
\text { акумуляторів }\end{array}$ & 17 & $17-23$ & 70 \\
\hline 24 & $\begin{array}{l}\text { Технічний огляд i ремонт } \\
\text { пристроїв, радіоприладів }\end{array}$ & 17 & $17-24$ & 60 \\
\hline 25 & $\begin{array}{l}\text { Прибирання пасажирського состава } 3 \text { колій } \\
\text { ремонту }\end{array}$ & $\begin{array}{l}20 \\
21 \\
22 \\
23 \\
24\end{array}$ & $\begin{array}{l}20-25 \\
21-25 \\
22-25 \\
23-25 \\
24-25\end{array}$ & $\begin{array}{l}5 \\
5 \\
5 \\
5 \\
5\end{array}$ \\
\hline 26 & $\begin{array}{l}\text { Подача пасажирського состава } \\
\text { екіпірування }\end{array}$ & 25 & $25-26$ & 5 \\
\hline 27 & $\begin{array}{l}\text { Екіпірування пасажирського вагона паливом та } \\
\text { водою }\end{array}$ & 26 & $26-27$ & 30 \\
\hline 28 & Внутрішнє прибирання приміщення вагонів & 26 & $26-28$ & 90 \\
\hline 29 & $\begin{array}{lcc}\text { Екіпірування } & \text { інвентарем, } & \text { продуктами } \\
\text { харчування, постільною білизною } & \\
\end{array}$ & 26 & $26-29$ & 60 \\
\hline 31 & $\begin{array}{l}\text { Приймання } \\
\text { провідниками }\end{array}$ & $\begin{array}{l}27 \\
28 \\
29\end{array}$ & $\begin{array}{l}27-31 \\
28-31 \\
29-31\end{array}$ & $\begin{array}{l}5 \\
5 \\
5\end{array}$ \\
\hline 33 & $\begin{array}{lccc}\text { Обробка та екіпірування } & \text { поштових } & \text { та } \\
\text { багажних вагонів } & & \end{array}$ & 16 & $16-33$ & 90 \\
\hline 30 & Обробка та екіпірування вагонів-ресторанів & 19 & $19-30$ & 90 \\
\hline
\end{tabular}


Збірник наукових праць Української державної академії залізничного транспорту

Продовження таблиці

\begin{tabular}{|c|l|c|c|c|}
\hline 1 & \multicolumn{1}{|c|}{2} & 3 & 4 & 5 \\
\hline 31 & Подавання до состава резервних вагонів & 18 & $18-31$ & 10 \\
\hline 31 & Подавання до состава вагонів-ресторанів & 30 & $30-31$ & 10 \\
\hline 32 & Закінчення формування схеми пасажирського состава & 31 & $31-32$ & 60 \\
\hline 34 & $\begin{array}{l}\text { Приймання состава комісією та подавання його до } \\
\text { перонних колій }\end{array}$ & 32 & $32-34$ & 10 \\
\hline 34 & Причеплення поштових та багажних вагонів & 33 & $33-34$ & 10 \\
\hline 35 & Посадка пасажирів & 34 & $34-35$ & 30 \\
\hline 36 & Причеплення поїзного локомотива & 34 & $34-36$ & 10 \\
\hline 37 & Опробування автогальм & 35 & $35-37$ & 0 \\
\hline 38 & $\begin{array}{l}\text { Приведення поїзда в рух та звільнення горловини } \\
\text { станції }\end{array}$ & 36 & $36-37$ & 15 \\
\hline
\end{tabular}

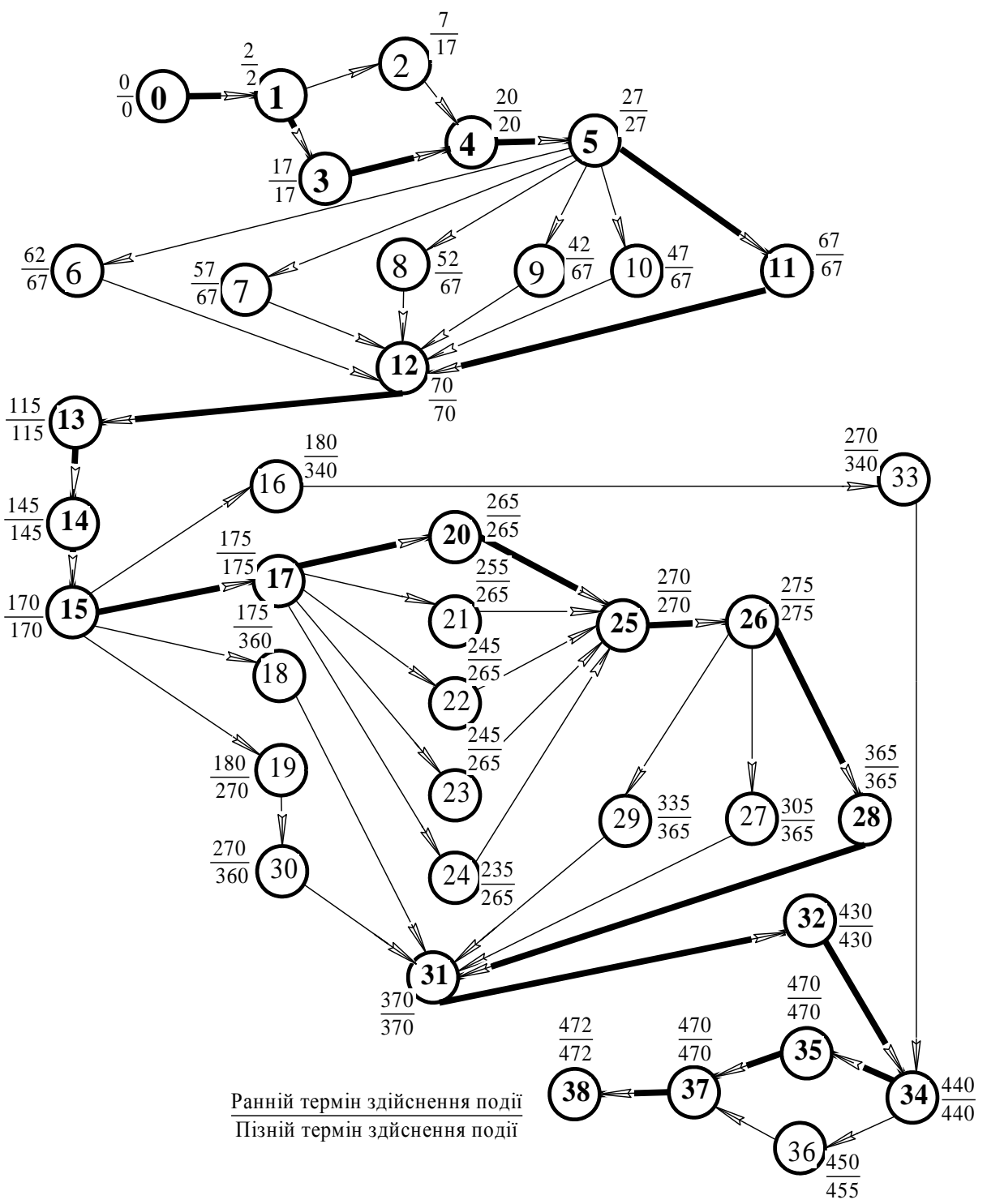

Рис. 2. Критичний шлях для графа обслуговування пасажирського состава 
Критичний шлях являє собою послідовність тих робіт, які повинні бути виконані точно у відведений на них час. Будь-яка затримка у виконанні робіт, що належать критичному шляху, призведе до зриву всього комплексу. Критичний шлях дає можливість визначити «вузькі» місця в процесі всього комплексу робіт 3 обслуговування состава та потребує особливої уваги. Роботи, що належать критичному шляху, потребують для їх виконання кваліфікованих працівників 3 більш високою оплатою праці. Для скорочення часу на обробку составів доцільно поєднувати окремі професії.

Це дозволить звільнити рухомий склад; скоротити невиробничий простій составів та бригад провідників; вивільнити бригади провідників; ефективніше використовувати технічне оснащення; зменшити витрати на підготовку составів до рейсу; зменшити витрати матеріалів на утримання вагонів; оптимізувати чисельність робітників станції.

Висновки. Для оптимізації технології обслуговування составів у пасажирському комплексі визначено роботи, які розташовані на критичному шляху. Їх якісне та своєчасне виконання дозволить більш раціонально організувати процес обслуговування составів пасажирських поїздів.

\section{Список літератури}

1. Про затвердження Державної програми реформування залізничного транспорту на 2010-2019 роки [Електронний ресурс]: постанова Кабінету Міністрів України від 16 грудня 2009 р. № 1390. - Режим доступу: http://dokcument.ua. - Назва з екрана.

2. Шиш, В.О. Особливості розробки Генеральної схеми розвитку залізничного транспорту України до 2020 року [Текст] / В.О. Шиш // Залізничний транспорт України. 2009. - № 6(79). - С. 38-40.

3. Логинов, С.И. Развитие пассажирских и технических станций [Текст] : учеб. пособие / С.И. Логинов. - Л.: ЛИИЖТ, 1986. - 55 с.

4. Сугоровский, А.В. Обоснование этапности развития пассажирских технических станций [Текст]: автореф. дис.... канд. техн. наук: 05.22.08 / А.В. Сугоровский. - С.Пб., 2010. - 22 c.

5. Бекжанова, C.Е. Выбор рациональных конструкций и организация параметров горловин пассажирских станций [Текст]: автореф. дис.... канд. техн. наук: 05.22.08 / С.Е. Бекжанова. - М.: МИИТ, 1990. - 19 с.

6. Вакуленко, С.П. Выбор рациональных схем и емкости путевого развития пассажирских технических станций [Текст]: автореф. дис.... канд. техн. наук: 05.22.08 / С.П. Вакуленко. - М.: МИИТ, 1989. - 26 с.

7. Кирсанов, А.С. Потребный уровень технического оснащения и путевого развития пассажирских технических станций [Текст] / А.С. Кирсанов, Л.А. Блинова // Вестник ВНИИЖТ. - 1989. - №4. - С. 7-9.

8. Каширцева, Т.И. Выбор рационального соотношения объемов работы и технического оснащения ПТС [Текст]: автореф. дис.... канд. техн. наук: 05.22.08 / Т.И. Каширцева. - М. : МИИТ, 2002. - 16 с.

9. Бутько, Т.В. Розроблення адаптивної моделі поїздоутворення пасажирських составів на основі теорії нечітких множин [Текст] / Т.В. Бутько, А.В. Прохорченко // Зб.наук.праць. Харків: УкрДАЗТ, 2005. - Вип. 68. - С. 25-33. 


\begin{abstract}
10. Бутько, Т.В. Удосконалення технології составоутворення на пасажирських технічних станціях [Текст] / Т.В.Бутько, А.В. Прохорченко // Залізничний транспорт України. - 2006. - № 4. - С. 43-45.

11. Шапкин, А.С. Математические методы и модели исследования операцій [Текст] : учебник / А.С. Шапкин, В.А. Шапкин. - М.: Издательско-торговая корпорация «Дашков и $\mathrm{K}^{\circ} \gg, 2009 .-400 \mathrm{c}$.
\end{abstract}

Ключові слова: технологія роботи, пасажирський комплекс, подія, робота, критичний шлях, ранній термін здійснення події, пізній термін здійснення події.

\begin{abstract}
Анотаціï
Проаналізовано вплив технічного оснащення й технології роботи пасажирського комплексу на ефективність обслуговування составів. Для вибору раціональної технології обслуговування составів запропоновано використовувати метод сітьового програмування. На основі побудованого орієнтованого графа розраховано основні параметри сітьової моделі. За проведеними розрахунками визначено послідовність робіт, що розташовані на критичному шляху.
\end{abstract}

Проанализировано влияние технического оснащения и технологии работы пассажирского комплекса на эффективность обслуживания составов. Для выбора рациональной технологии обслуживания составов предложено использовать метод сетевого программирования. На основе построенного ориентированного графа рассчитаны основные параметры сетевой модели. По проведенным расчетам определена последовательность работ, лежащих на критическом пути.

In the work of the impact of technical equipment and technology of the operation of passenger complex of the efficiency of service compositions. For the selection of rational technology of servicing formulations proposed to use the method of network programming. On the basis of the built a directed graph are calculated major parameters of the network model. According to the estimates carried out is defined sequence of activities, which lie on the critical path. 